\title{
An Integrated Model for Investigating the Impact of Social CRM on Performance of SMEs in Developing Countries: Instrument Development
}

\author{
Fathey Mohammed*1 ${ }^{1}$, Syahida Binti Hassan ${ }^{1}$, Rahayu Binti Ahmad ${ }^{1}$, Yousef \\ Fazea $^{2}$ \\ ${ }^{1}$ School of Computing, Universiti Utara Malaysia (UUM), 06010 Sintok, Kedah, \\ Malaysia \\ ${ }^{2}$ Department of Computer \& Information Technology, Marshall University, 1 John \\ Marshall Drive, Huntington, WV 25755, USA \\ fathey.m.ye@gmail.com
}

\begin{abstract}
Social media have emerged as a revolutionary Internet-related technology and have become a primary source of products' information for customers. Social media can be used by SMEs to develop social CRM in improving their performance. However, there is a lack of understanding regarding the significant factors that SMEs, more specific in developing countries, need to consider when assigning their resources for social CRM adoption. This research proposes an integrated model to investigate the impact of social CRM on the SMEs performance in developing countries based on three dominant theoretical models; Fit-Viability Model (FVM), Network Externalities and Resources Based View (RBV). An instrument is also developed to help collecting the required data to empirically verify the proposed model. The proposed model may help SMEs to make a decision to adopt social CRM based on assessing the fitness of social media to the CRM tasks and the readiness of the firm to implement social CRM, so that the performance can be improved.
\end{abstract}

Keywords: Social CRM, SMEs, performance, FVM, RBV, network externalities, integrated model, instrument, content validity. 


\section{Introduction}

Customer Relationship Management (CRM) systems are used to manage organization's interaction with customers by analyzing data from different resources (e.g. company's website, telephone, email, marketing materials, social media, etc.) (Bardicchia, 2020). CRM helps firms get more information about their target customers and identify the best way to cater for their needs, which assists in customer retention and drives sales growth (Dyche, 2002). However, the lack of resources makes Small and Medium Enterprises (SMEs) unable to implement CRM system (Zhou, Xiao, Liu, \& Ai, 2013). Despite their contribution to economic growth, SMEs in developing countries are confronted with a lack of technological know-how that may hinder their survival (Banwo, Du, \& Onokala, 2017; Sorasalmi $\&$ Tuovinen, 2016). However, the emerging of social media and the easy access to analytical tools may help SMEs overcome the challenge of having traditional CRM.

Social Media provides a multi-directional communication mode thatcan help SMEs to interact with customers and potential customers (Banwo et al., 2017; Choudhury \& Harrigan, 2014; Faase, Helms, \& Spruit, 2011; Jinyoung Shin, 2020; Lehmkuhl, 2014; Reinhold \& Alt, 2012). Integrating Social Media tools into the process of managing the relationship with customers is referred as Social CRM (or sCRM) (Choudhury \& Harrigan, 2014). According to Küpper, Lehmkuhl, Wittkuhn, Wieneke, \& Jung, (2015), Social CRM is a strategy of adding value for firms and their target groups using social media tools. sCRM is described as a complement of CRM which allows firms to interact with customers to create long-term relationships by engaging the customer through social media (Lehmkuhl \& Jung, 2013; Marolt, Pucihar, \& Zimmermann, 2015).

Number of studies have investigated the impact of social media adoption on the performance in terms of benefits for organizations and customers (Baird \& Parasnis, 2011; Choudhury \& Harrigan, 2014; Harrigan \& Miles, 2014; Harrigan, Soutar, Choudhury, \& Lowe, 2015; Rodriguez, Peterson, \& Ajjan, 2015; Trainor, Andzulis, Rapp, \& Agnihotri, 2014). However, limited research has been done to study the impact of social CRM on firms' performance, more specific within SMEs environment (Acker, Gröne, Akkad, Pötscher, \& Yazbek, 2011; Choudhury \& Harrigan, 2014; Harrigan \& Miles, 2014). The literature may not have provided enough evidence of the significant factors that SMEs need to consider when assigning their resources to implement social CRM (Banwo et al., 2017). SMEs, especially those in developing countries, should be aware of the factors influencing their performance using sCRM (Marolt et al., 2015). Moreover, the studies that identify performance outcomes for social CRM suggest further empirical research on the impact of social CRM on performance outcomes (Aldoseri, Al Mubarak, \& El Hajjar, 2019; Diffley, McCole, \& Carvajal-Trujillo, 2018; Hassan, Mohamed 
Haniba, \& Ahmad, 2019; Küpper, 2016; Marolt et al., 2015). Therefore, to improve the understanding of the impact of social CRM on the performance of SMEs in developing countries, this study aims at proposing an integrated model to identify the influencing factors.

\section{Related Work}

Literature shows that some research has been conducted to investigate sCRM adoption and its impact on the firm's performance. Yawised, Torugsa, \& O'Donohue, (2017) investigated the current level of Australian SMEs adoption of sCRM, types of social networking sites used, and the benefits and challenges of implementing sCRM. It was concluded that sCRM implementation can, in the long term, increase customer retention; however, inability to effectively implement sCRM hinders the success of sCRM adoption. Another study by Ahani, Rahim, \& Nilashi, (2017) examined the factors influencing the adoption of social CRM by Malaysian SMEs. A model was proposed based on Technology Organization Environment and Process model. The identified factors were ranked to help SMEs' managers planning to adopt sCRM. However, the impact of sCRM on SMEs' performance was not investigated. On the other hand, Sigala, (2011) explored to what extend Greek tourism companies are ready to adopt sCRM. The effect of sCRM on the companies' performance in terms of outcomes related to loyalty of the customer, customer profitability, level of service quality, and company reputation was studied. Trainor et al., (2014) showed that sCRM capabilities positively effects the performance by measurements related to customer satisfaction and customer loyalty based on the evidence from broad spectrum of industries in United States.

In addition, a study by Choudhury \& Harrigan, (2014) demonstrated that customer relationship performance is not affected by customer engagement using sCRM, while it is influenced by the relational information processes in sCRM. In contrast, Harrigan et al., (2015) showed that there is no relationship between relational information processes and customer relationship performance. Wittkuhn, Lehmkuhl, Küpper, \& Jung, (2015) who studied the impact of sCRM resources and capabilities on organization performance proposd a performance dimension modelbased on Resource-based View (RBV) theory, dynamic capabilities and the balanced-scorecard approach. Propositions regarding customer-centric resources and capabilities were proposed, but no empirical evidence was provided.

Wang \& Kim, (2017) studied the impact of sCRM on business performance. An integrated model based on two theories; RBV and dynamic capabilities was proposed. The results showed that SCRM capabilities improve customer engagement and firm performance. In addition, social media usage moderates the relationship between sCRM capabilities and performance. Moreover, Charoensukmongkol \& Sasatanun, (2017) examined the impact of sCRM on business performance satisfaction in Thai microenterprises. Findings demonstrated 
the positive effect of sCRM usage on entrepreneurs' satisfaction of their business performance. The findings also showed that the social competency of entrepreneurs has a moderating role on the impact of sCRM and business performance. Diffley, McCole, \& Carvajal-Trujillo, (2018) examined the chain-of-effects as a result of sCRM processes towards enhancing hotels' performance in Ireland. Findings showed that SCRM processes enhance service innovation, which enables a customer-linking capability and improves customer performance.

Aldoseri et al. (2019) studied the impact of sCRM on the performance of SMEs. An empirical study was conducted to verify and test a model constructed by hypothesizing the relationships between CRM implementation and social media usage as independent variables and the performance of SME as the dependent variable. Data was collected using a survey that was distributed to the employees working in SMEs in Bahrain. Performance was measured by sales growth, customer satisfaction, customer loyalty, employees' satisfaction, and top management satisfaction. The results confirmed the positive impact of CRM and social media usage on the firm's performance.

Yu and Lee (2018) proposed a model based on dynamic capability theory to examine the mediation role social CRM competence and capability on the link of customer relationship orientation to CRM performance. An empirical study was conducted to test the proposed model, by obtaining data using a questionnaire sent by e-mail to senior marketing managers, executives and directors of SMEs in China. The results illustrated that, through a range of relationships and processes, sCRM capability positively influence CRM performance. Marolt, Zimmermann, and Pucihar (2018) studied the antecedents of the intensity of sCRM, its use dimensions, and its impact on performance. A qualitative research approach using the case study method through content analysis and interviews was applied to examine the factors affecting the use of sCRM and its outcomes in the context of SMEs. The results illustrated that relative advantages, compatibility, top management support, organizational culture, technology readiness and external pressure affect the intensity of sCRM use. In addition, it was implied that more intensive use of sCRM improves performance outcomes.

In addition, based on knowledge-based view theory, and social network capabilities, Cheng and Shiu (2019) studied the role of social media tools capability and customer information processing capability on leveraging SCRM to improve the innovation performance in terms of customer engagement. Survey using questionnaire was conducted to collect from 317 SMEs in China. Findings demonstrated that the more customer engagement using social media the more enhanced performance. Findings also showed that SMEs with high social media network capability have a more propensity to take advantage of resources embedded in the relationships with customers.

Guha, Harrigan, and Soutar (2018) investigated the underpinning factors of 
sCRM, customer engagement behaviours, and SCRM as dynamic capability. The data was collected by in-depth interviews with SMEs managers in Australia. Results illustrated that the limited resources, data management, privacy and control determine SMEs intention to use social media. Further, it was confirmed that SCRM can be characterized as a dynamic capability in SMEs. Marolt (2018) proposed a model for sCRM adoption by Slovenian SMEs and its role on customer relationship performance. Mixed method approach was employed to empirically verify the proposed model. Qualitative phase was used to develop the model and guided the data collection using questionnaire for the quantitative phase. Results revealed that the factors influencing sCRM adoption are diverse, ranging from technological, organizational, to environmental. The also results showed that the use of social CRM positively affects customer relationship performance.

Bridge (2017) explored the effect of sCRM on small businesses. Agency theory and resource-based view guided a qualitative study through interviews. Three themes were identified by interviewing the employee responsible for managing the social media content in 10 small businesses. These themes are visibility, interactivity, and being relational which are critical for social CRM success. Hassan et al. (2019) studied the impact of sCRM among SMEs. Quantitative data was gathered through questionnaires from SMEs owned by Muslims in Malaysia. Findings revealed that ICT adoption has direct and indirect effect on sCRM performance. In addition, perceived value controls the link of customer information management to sCRM performance.

It can be concluded that there has been some research and discussion conducted in the field of social CRM, however most of the research was on the adoption of social CRM in organizations, leaving gaps from the context of SMEs, especially in developing countries. Furthermore, the related literature on the impact of social CRM on the firms' performance mainly proposed measurements of different performance dimensions. More empirical research are needed to better understand the factors affecting the use of SCRM to enhance the SMEs performance in developing countries.

\section{Integrated Theoretical Model}

Measuring the impact of IT innovation on the organization performance is a complex problem that only can be addressed by insights from multiple theoretical paradigms (Melville, Kraemer, \& Gurbaxani, 2004). Researchers have adopted diverse theories to identify the factors related to the application of information technology in organizations (Kling, 1980; Markus \& Robey, 1988). Since this research concerns the performance of SMEs by adopting SCRM, theories/models related to measuring the performance by considering the context of SMEs and social media should be considered. Fit Viability Model (FVM), which is an extension of Task-Technology Fit (TTF) defines the factors predicting the use of 
technology and its impact on the performance in organizations (Baas \& van Rekom, 2010; Goodhue \& Thompson, 1995; Tjan, 2001).

When an innovative technology is adopted to implement a system in an organization, a degree of risk may be involved. Thus, a model that could predict the successful application of this technology to the context of the organization will be an advantage. The readiness of a context and the characteristics of technology affect the applicability of that technology in that specific context (Mohammed, Ibrahim, Nilashi, \& Alzurqa, 2017). FVM model can be useful in establishing whether or not sCRM can enhance the performance of SMEs. It involves technology features (fitness) and organization readiness (viability) (Liang, Huang, Yeh, \& Lin, 2007). In the current study, Fit describes how far SCRM is appropriate for the SMEs businesses tasks. Viability in the context of SMEs describes how much added-value might SCRM bring to the SMEs performance and to what extent SMEs are ready to adopt SCRM.

In the context of social CRM, Resource Based View (RBV) theory and network externalities are widely accepted and verified (Ahani et al., 2017; Banwo et al., 2017; Lehmkuhl, 2014; Trainor et al., 2014; Wittkuhn et al., 2015). The theory of network externalities highlights that the larger network of technology users, the more added value for this technology. This applies to sCRM as social media tools allow the engagement of a large number of users (Banwo et al., 2017; Gu, Davis, Cao, \& Vogt, 2017). Accordingly, social network externalities may influence the fitness of social CRM to SMEs task requirements in terms of high customer engagement. In addition, Resource-based View (RBV) theory emphasizes that firms can have competitive advantage if they possess valuable, rare and non-substitutable resources (Barney, 1991). In regard to SMEs, resources including human, technology, and business can be integrated to build up CRM capabilities which can enhance the performance (Rapp, Trainor, \& Agnihotri, 2010; Trainor et al., 2014). Based on the literature, resources such as Internal Financial Resources (Hasani, Bojei, \& Dehghantanha, 2017; Sophonthummapharn, 2009), Manager Innovativeness (Hasani et al., 2017; Parveen, Jaafar, \& Ainin, 2016), IT/IS Knowledge of Employees (Ahani et al., 2017), Top Management Support (Ahani et al., 2017; Li, 2020) and Governmental Support (Ahani et al., 2017; Hasani et al., 2017) can have a significance impact on the readiness of the firms to adopt sCRM. Accordingly, by considering the "Viability" dimension of FVM model, a link between the RBV and viability is proposed.

Therefore, an integrated model is proposed based on FVM, network externalities and $\mathrm{RBV}$ to investigate the factors influencing the adoption of social CRM to improve SMEs performance in developing countries. Fig. 1 represents the proposed model.

\section{Instrument Development}


Instrument is a predefined set of measures, and it is extensively utilized in research (Oates, 2005). According to Bhattacherjee (2012), an instrument encompasses a set of items intended to catch respondents' responses in a standardized manner. The instrument provides a platform to identify the exact sample and helps the researcher to formulate a clear and easy to understand questionnaire (Creswell, 2013). It provides the measurements of the variables in the theoretical framework. Accordingly, instrument development is considered as an integral stage of any research and an important aspect of the research process (Sekaran \& Bougie, 2012).

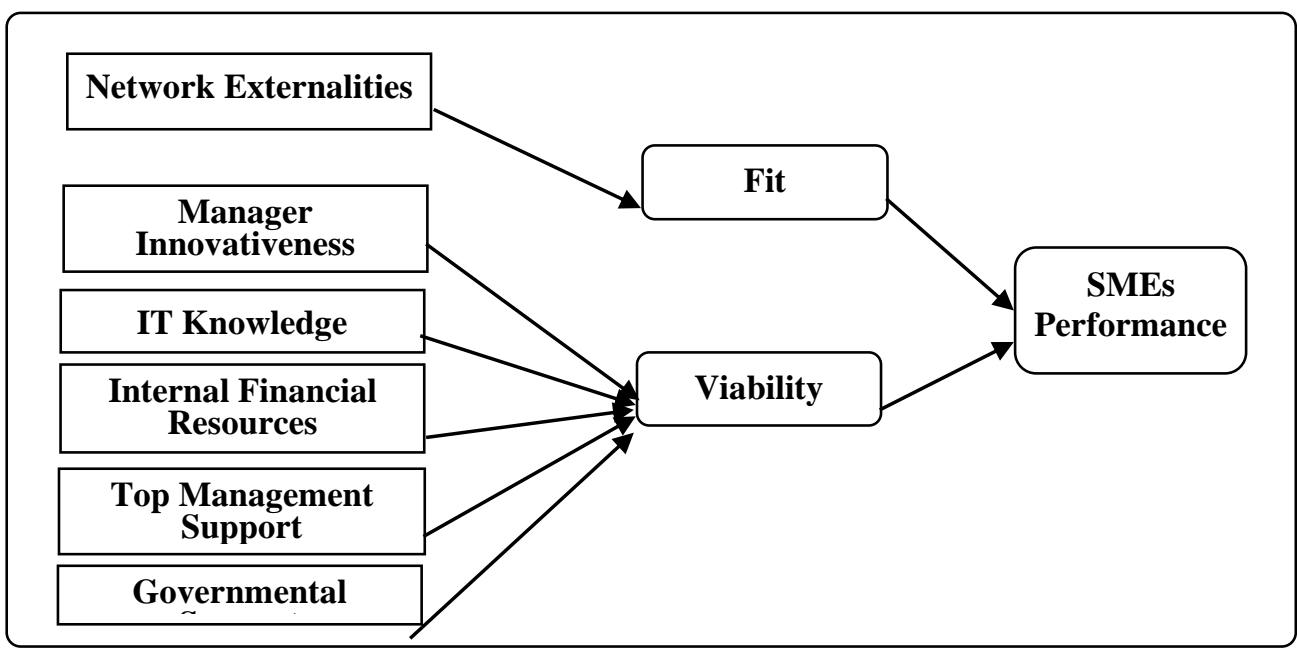

Fig. 1: The proposed model

In the current study, an instrument is developed to get the data for testing the proposed model and thereby identifying the impact of sCRM fit and viability on SMEs' performance. To develop the instrument, the variables constructing the proposed model are operationalized based on the context of the study (See Table 1). Then, items are derived from original measurements, which had been applied in various research areas in the literature. This helps to establish the validity of instrument (Agarwal, 2011). However, to enhance the validity of the instrument, content validity by experts is conducted.

\subsection{Content Validity:}

Content validity means that to what extent the group of items measuring each construct, taken together, constitute an adequate operational definition of the construct (Polit \& Beck, 2006). To ensure the instrument content validity of the current study, three senior researchers assessed whether the construct items represent the entire range of possible measures of the construct dimensions. To facilitate the content validity assessment, a form was developed to allow the experts 
to assess the relevance and clarity of the measurements. The form was designed so that the expert can evaluate the relevance of each item by assigning a number $(1,2$ or 3); 1 means the item is not representative, 2 means the item is somehow representative and 3 means that the item is representative. Similarly, the expert can assess the clarity of the items ( 1 means the item is not clear, 2 means the item needs revision, and 3 means the item is clear). In addition, a space was provided to get the experts comments for each item and the whole scale in each construct. The Appendix presents the evaluators' responses and comments.

Table 1: The constructs operational definitions

\begin{tabular}{|c|c|}
\hline The construct & Operational Definition \\
\hline $\begin{array}{l}\text { Internal Financial } \\
\text { Resources }\end{array}$ & $\begin{array}{l}\text { Financial investment required to customise the company } \\
\text { chosen social media solution to meet its own needs and to train } \\
\text { staff to work effectively with the sCRM system. }\end{array}$ \\
\hline Governmental Support & $\begin{array}{l}\text { The government policies, initiatives, incentives and agencies } \\
\text { that are established to support the adoption of new technologies } \\
\text { or innovations. }\end{array}$ \\
\hline $\begin{array}{c}\text { Manager } \\
\text { Innovativeness }\end{array}$ & $\begin{array}{l}\text { Manager's willingness to adopt new technologies and bring } \\
\text { new experiences to his company. }\end{array}$ \\
\hline $\begin{array}{l}\text { IT/IS Knowledge of } \\
\text { Employees }\end{array}$ & Having enough knowledge about using social media for CRM. \\
\hline $\begin{array}{l}\text { Top Management } \\
\text { Support }\end{array}$ & $\begin{array}{l}\text { The degree to which top management can prepare fertile } \\
\text { environment by providing resources to adopting sCRM. }\end{array}$ \\
\hline Viability & $\begin{array}{l}\text { The extent to which the SMEs are ready for the social media as } \\
\text { well as the extent to the value-added potential of using social } \\
\text { media in CRM. }\end{array}$ \\
\hline Network externalities & $\begin{array}{l}\text { To what extend CRM is linked to the number of customers } \\
\text { who use social media tools. }\end{array}$ \\
\hline Fit & $\begin{array}{l}\text { To what extend social media features align with the } \\
\text { requirements of a task or tasks to achieve CRM goals. }\end{array}$ \\
\hline Performance & $\begin{array}{l}\text { - A measure of how well SMEs are managed and the value } \\
\text { they deliver to customers and other stakeholders. } \\
\text { - Managers' perceptions of how the organization performed on } \\
\text { multiple indicators of organizational performance relative to } \\
\text { its competitors. } \\
\text { - The actual benefits SMEs received from using social media } \\
\text { in terms of both financial and nonfinancial performances. }\end{array}$ \\
\hline
\end{tabular}

\subsection{Validity Analysis}

The experts' evaluation of the items' relevance and clarity for each construct was 
analysed. The content validity index (CVI) which is the most widely reported measure of content validity was used (Polit \& Beck, 2006). There are two types of CVI. Item-level CVI (I-CVI), which involves the content validity of individual items, and the Scale-level CVI (S-CVI), which measures the content validity of the overall scale (Lynn, 1986). The I-CVI is computed as the number of experts giving a rating of item relevance divided by the total number of experts. The S-CVI can be computed using two ways. One requires universal agreement among experts, and it is called S-CVI/UA. It is the proportion of items on an instrument that achieved an agreement rating of relevance by all the experts. The other way is calculating the average of I-CVI across items, which is called S-CVI/Ave. For the current study instrument, the CVI for items' relevance and clarity was calculated. For the items' relevance, results show that I-CVI for three items does not fit the criteria for item acceptability suggested by (Lynn, 1986; Polit, Beck, \& Owen, 2007), which must be 1 for 3-5 experts. However, the S-CVI results show that SCVI/UA and S-CVI/Ave are 0.90 and 0.97 , respectively (See Table 2). These values are quite above the lower limit of acceptability for S-CVI identified by Davis (1992), which is 0.80 .

On the other hand, computing I-CVI for items' clarity shows that 4 items are not clear enough (0.67) (See Table 3). The experts provided comments to improve the items' clarity. In addition, S-CVI/UA and S-CVI/Ave for items' clarity show satisfied values with 0.88 and 0.96 , respectively (See Table 2).

Table 2: Scale-level content validity index (S-CVI)

\begin{tabular}{|l|c|c|}
\hline & Relevance & Clarity \\
\hline$\underline{\text { S-CVI/Ave }}$ & 0.97 & 0.96 \\
\hline$\underline{\text { Total Agreement }}$ & 30 & 29 \\
\hline$\underline{\text { S-CVI/UA }}$ & 0.90 & 0.88 \\
\hline
\end{tabular}

Accordingly, the instrument was modified based on the comments from the evaluators. Table 4 represents the revised scale measurements.

\section{Discussion}

This study aimed at providing a theoretically grounded conceptualization for the impact of integrating social media in CRM strategies and implementations on the performance of SMEs. The network externality characteristic of social media may make it perfect for CRM tasks. However, to successfully integrate social media tools with CRM system so that the firm's performance can be improved, the firm's internal resources should be analyzed to identify its capabilities in formulating a strategy to achieve sustainable competitive advantages. Accordingly, this study contributes to the literature on the impact of technology on SMEs' performance by providing holistic insight incorporating two main aspects; organizational readiness based on RBV theory and technology characteristics based on Network externality theory. Additionally, RBV and Network externality theories were integrated with 
FVM as the underpinning theory of the proposed model of the sCRM impact on SMEs' performance. The proposed model can offer a framework for further conceptual and empirical research on social CRM and its implications for enhancing the performance of firms. Moreover, it supports the argument that integrating social media tools to implement CRM can positively influence the firm performance by considering SMEs' firm-level capabilities and internal resources. This is consistent with the literature on the impact of adopting technology innovations on the performance, which suggests that technology alone may not be sufficient to gain a competitive advantage (Baas \& van Rekom, 2010; Goodhue \& Thompson, 1995; Ikechukwu, 2019; Liang et al., 2007; Tjan, 2001). 
Table 3: Item-level content validity index (I-CVI)

\begin{tabular}{|c|c|c|c|c|c|c|c|c|c|c|c|}
\hline \multirow{2}{*}{ Construct } & \multirow{2}{*}{$\begin{array}{c}\text { Item } \\
\text { No. }\end{array}$} & \multicolumn{3}{|c|}{ Relevance Rating } & \multicolumn{3}{|c|}{ Clarity Rating } & \multicolumn{2}{|c|}{$\begin{array}{c}\text { NO. } \\
\text { agreement }\end{array}$} & \multicolumn{2}{|c|}{ I-CVI } \\
\hline & & $\begin{array}{c}\text { Expert } \\
1\end{array}$ & $\begin{array}{c}\text { Expert } \\
2\end{array}$ & $\begin{array}{c}\text { Expert } \\
3\end{array}$ & $\begin{array}{c}\text { Expert } \\
1\end{array}$ & $\begin{array}{c}\text { Expert } \\
2\end{array}$ & $\begin{array}{c}\text { Expert } \\
\mathbf{3}\end{array}$ & $\begin{array}{c}\text { Relev- } \\
\text { ance }\end{array}$ & $\begin{array}{l}\text { Clar- } \\
\text { ity }\end{array}$ & $\begin{array}{l}\text { Relev- } \\
\text { ance }\end{array}$ & $\begin{array}{c}\text { Clar- } \\
\text { ity }\end{array}$ \\
\hline \multirow{2}{*}{$\begin{array}{c}\text { Internal } \\
\text { Financial } \\
\text { Resources }\end{array}$} & 1 & 3 & 3 & 3 & 3 & 3 & 3 & 3 & 3 & 1 & 1 \\
\hline & 2 & 3 & 3 & 3 & 3 & 3 & 3 & 3 & 3 & 1 & 1 \\
\hline \multirow{2}{*}{$\begin{array}{c}\text { Governmental } \\
\text { Support }\end{array}$} & 1 & 3 & 3 & 3 & 3 & 3 & 3 & 3 & 3 & 1 & 1 \\
\hline & 2 & 3 & 2 & 2 & 3 & 2 & 1 & 3 & 2 & 1 & 0.67 \\
\hline \multirow{3}{*}{$\begin{array}{c}\text { Manager } \\
\text { Innovativeness }\end{array}$} & 1 & 3 & 3 & 3 & 2 & 3 & 3 & 3 & 3 & 1 & 1 \\
\hline & 2 & 3 & 3 & 3 & 3 & 3 & 3 & 3 & 3 & 1 & 1 \\
\hline & 3 & 3 & 3 & 3 & 3 & 3 & 3 & 3 & 3 & 1 & 1 \\
\hline \multirow{3}{*}{$\begin{array}{c}\text { IT/IS } \\
\text { Knowledge of } \\
\text { Employees }\end{array}$} & 1 & 3 & 2 & 2 & 3 & 2 & 2 & 3 & 3 & 1 & 1 \\
\hline & 2 & 3 & 2 & 2 & 3 & 2 & 2 & 3 & 3 & 1 & 1 \\
\hline & 3 & 3 & 2 & 2 & 3 & 2 & 2 & 3 & 3 & 1 & 1 \\
\hline \multirow{5}{*}{$\begin{array}{c}\text { Top } \\
\text { Management } \\
\text { Support }\end{array}$} & 1 & 3 & 3 & 3 & 3 & 3 & 3 & 3 & 3 & 1 & 1 \\
\hline & 2 & 3 & 1 & 3 & 3 & 2 & 1 & 2 & 2 & 0.67 & 0.67 \\
\hline & 3 & 3 & 3 & 3 & 3 & 3 & 3 & 3 & 3 & 1 & 1 \\
\hline & 4 & 3 & 3 & 3 & 3 & 3 & 3 & 3 & 3 & 1 & 1 \\
\hline & 5 & 3 & 3 & 3 & 3 & 3 & 3 & 3 & 3 & 1 & 1 \\
\hline \multirow{3}{*}{ Viability } & 1 & 3 & 3 & 2 & 3 & 2 & 1 & 3 & 2 & 1 & 0.67 \\
\hline & 2 & 3 & 3 & 3 & 3 & 3 & 3 & 3 & 3 & 1 & 1 \\
\hline & 3 & 3 & 2 & 3 & 3 & 3 & 3 & 3 & 3 & 1 & 1 \\
\hline \multirow{4}{*}{$\begin{array}{c}\text { Network } \\
\text { externalities }\end{array}$} & 1 & 2 & 1 & 3 & 3 & 3 & 3 & 2 & 3 & 0.67 & 1 \\
\hline & 2 & 3 & 3 & 3 & 3 & 3 & 3 & 3 & 3 & 1 & 1 \\
\hline & 3 & 3 & 2 & 3 & 3 & 2 & 3 & 3 & 3 & 1 & 1 \\
\hline & 4 & 3 & 3 & 3 & 3 & 3 & 3 & 3 & 3 & 1 & 1 \\
\hline \multirow{6}{*}{ Fit } & 1 & 3 & 3 & 3 & 3 & 3 & 3 & 3 & 3 & 1 & 1 \\
\hline & 2 & 3 & 3 & 3 & 3 & 3 & 3 & 3 & 3 & 1 & 1 \\
\hline & 3 & 3 & 3 & 3 & 3 & 3 & 3 & 3 & 3 & 1 & 1 \\
\hline & 4 & 3 & 3 & 3 & 3 & 3 & 3 & 3 & 3 & 1 & 1 \\
\hline & 5 & 3 & 3 & 3 & 3 & 3 & 3 & 3 & 3 & 1 & 1 \\
\hline & 6 & 3 & 1 & 3 & 3 & 1 & 3 & 2 & 2 & 0.67 & 0.67 \\
\hline \multirow{5}{*}{ Performance } & 1 & 2 & 3 & 3 & 2 & 3 & 3 & 3 & 3 & 1 & 1 \\
\hline & 2 & 2 & 3 & 3 & 2 & 3 & 3 & 3 & 3 & 1 & 1 \\
\hline & 3 & 2 & 3 & 3 & 2 & 3 & 3 & 3 & 3 & 1 & 1 \\
\hline & 4 & 2 & 3 & 3 & 2 & 3 & 3 & 3 & 3 & 1 & 1 \\
\hline & 5 & 2 & 3 & 3 & 2 & 3 & 3 & 3 & 3 & 1 & 1 \\
\hline
\end{tabular}


Table 4: Revised scale measurements

\begin{tabular}{|c|c|c|}
\hline 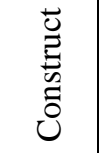 & Original Items & Revised Items \\
\hline \multirow{3}{*}{ 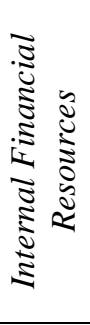 } & $\begin{array}{l}\text { Our firm has the financial resources to } \\
\text { adopt a sCRM application. }\end{array}$ & $\begin{array}{l}\text { Our firm has the financial resources to } \\
\text { adopt sCRM applications. }\end{array}$ \\
\hline & \multirow[t]{2}{*}{$\begin{array}{l}\text { Our firm has the financial resources to } \\
\text { maintain a sCRM application. }\end{array}$} & $\begin{array}{l}\text { Our firm has the financial resources to } \\
\text { allocate the necessary technological } \\
\text { resources and skills to use sCRM } \\
\text { applications. }\end{array}$ \\
\hline & & $\begin{array}{l}\text { Our firm has the financial resources to } \\
\text { maintain sCRM applications. }\end{array}$ \\
\hline \multirow{3}{*}{ 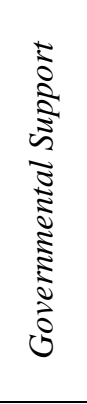 } & $\begin{array}{l}\text { We know that the government has } \\
\text { policies and initiatives encouraging } \\
\text { companies to adopt technologies. }\end{array}$ & $\begin{array}{l}\text { We know that government policies } \\
\text { encourage companies to adopt } \\
\text { technologies. }\end{array}$ \\
\hline & \multirow[t]{2}{*}{$\begin{array}{l}\text { We are aware of the existence of } \\
\text { government agencies providing services } \\
\text { toward e-business adoption. }\end{array}$} & $\begin{array}{l}\text { We are aware of the existence of } \\
\text { government agencies that provide } \\
\text { services toward technology adoption. }\end{array}$ \\
\hline & & $\begin{array}{l}\text { There are initiatives by the government } \\
\text { to facilitate the rate of adopting a } \\
\text { techno-relationship innovation such as } \\
\text { sCRM. }\end{array}$ \\
\hline \multirow{3}{*}{ 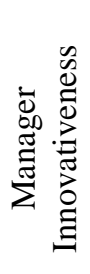 } & $\begin{array}{l}\text { Our manager frequently tries out new } \\
\text { ideas }\end{array}$ & $\begin{array}{l}\text { Our manager frequently tries out new } \\
\text { ideas. }\end{array}$ \\
\hline & $\begin{array}{l}\text { Our manager seeks out new ways to do } \\
\text { things }\end{array}$ & $\begin{array}{l}\text { Our manager seeks out new ways to } \\
\text { do things. }\end{array}$ \\
\hline & $\begin{array}{l}\text { Our manager often the first to use } \\
\text { technology for new services. }\end{array}$ & $\begin{array}{l}\text { Our manager often the first to use } \\
\text { technology for new services. }\end{array}$ \\
\hline \multirow{3}{*}{ 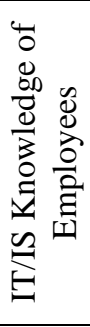 } & $\begin{array}{l}\text { Our employees are all technology- } \\
\text { literate. }\end{array}$ & Our employees are all IT-literate. \\
\hline & $\begin{array}{l}\text { There is at least one employee who was } \\
\text { a technology expert. }\end{array}$ & $\begin{array}{l}\text { There is at least one employee who is } \\
\text { an IT expert. }\end{array}$ \\
\hline & $\begin{array}{l}\text { We would rate our employees' } \\
\text { understanding of technology as very } \\
\text { good compared with other small } \\
\text { companies in the same industry. }\end{array}$ & $\begin{array}{l}\text { We would rate our employees' } \\
\text { understanding of IT as very good } \\
\text { compared with other small companies } \\
\text { in the same industry. }\end{array}$ \\
\hline \multirow{4}{*}{ 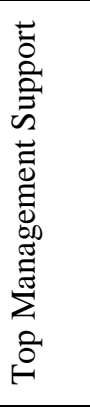 } & $\begin{array}{l}\text { Top manager is strongly committed to } \\
\text { the introduction of social media tools to } \\
\text { manage the relationship with customer. }\end{array}$ & $\begin{array}{l}\text { Top manager is strongly committed to } \\
\text { the introduction of social media tools } \\
\text { to manage the relationship with } \\
\text { customer. }\end{array}$ \\
\hline & $\begin{array}{l}\text { Top manager's enthusiasms in adopting } \\
\text { sCRM. }\end{array}$ & $\begin{array}{l}\text { Top manager has enthusiastic in } \\
\text { adopting sCRM. }\end{array}$ \\
\hline & $\begin{array}{l}\text { Top manager understands the benefits of } \\
\text { sCRM. }\end{array}$ & $\begin{array}{l}\text { Top manager understands the benefits } \\
\text { of sCRM. }\end{array}$ \\
\hline & $\begin{array}{l}\text { Top manager is supportive of the use of } \\
\text { social media in CRM operations. }\end{array}$ & $\begin{array}{l}\text { Top manager is supportive of the use } \\
\text { of social media in CRM operations. }\end{array}$ \\
\hline
\end{tabular}




\begin{tabular}{|c|c|c|}
\hline & $\begin{array}{l}\text { Top manager regards the application of } \\
\text { sCRM as one of the firm's top priorities. }\end{array}$ & $\begin{array}{l}\text { Top manager regards the application } \\
\text { of sCRM as one of the firm's top } \\
\text { priorities. }\end{array}$ \\
\hline \multirow{3}{*}{ 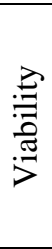 } & $\begin{array}{l}\text { The organization's capabilities and } \\
\text { current resources support sCRM. }\end{array}$ & $\begin{array}{l}\text { The firm's capabilities and current } \\
\text { resources support adopting sCRM. }\end{array}$ \\
\hline & $\begin{array}{l}\text { The organization can efficiently develop } \\
\text { sCRM applications. }\end{array}$ & $\begin{array}{l}\text { The firm can efficiently develop } \\
\text { sCRM applications. }\end{array}$ \\
\hline & $\begin{array}{l}\text { Social media is viable to implement } \\
\text { CRM operations in our firm. }\end{array}$ & $\begin{array}{l}\text { Social media is viable to implement } \\
\text { CRM operations in our firm. }\end{array}$ \\
\hline \multirow{5}{*}{ 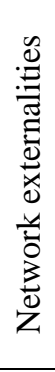 } & $\begin{array}{l}\text { If more and more customers follow us on } \\
\text { social media, then: }\end{array}$ & $\begin{array}{l}\text { If more and more customers follow us } \\
\text { on social media, then: }\end{array}$ \\
\hline & $\begin{array}{l}\text { - the quality of sCRM services is } \\
\text { increased; }\end{array}$ & $\begin{array}{l}\text { - variety of CRM services can be } \\
\text { provided; }\end{array}$ \\
\hline & $\begin{array}{l}\text { - variety of CRM services can be } \\
\text { provided; }\end{array}$ & $\begin{array}{l}\text { - the response speed of CRM service } \\
\text { is increased; }\end{array}$ \\
\hline & $\begin{array}{l}\text { - the response speed of CRM service } \\
\text { is increased; }\end{array}$ & \multirow[t]{2}{*}{$\begin{array}{l}\text { - the value of information is } \\
\text { increased. }\end{array}$} \\
\hline & - the value of information is increased. & \\
\hline \multirow{7}{*}{ 居 } & $\begin{array}{l}\text { In helping us to manage all company's } \\
\text { relationships and interactions with } \\
\text { customers and potential customers: }\end{array}$ & $\begin{array}{l}\text { In helping us to manage all company's } \\
\text { relationships and interactions with } \\
\text { customers and potential customers: }\end{array}$ \\
\hline & $\begin{array}{l}\text { - The functionalities of social media } \\
\text { are helpful. }\end{array}$ & $\begin{array}{l}\text { - The functionalities of social } \\
\text { media are helpful. }\end{array}$ \\
\hline & $\begin{array}{l}\text { - The functionalities of social media } \\
\text { are adequate. }\end{array}$ & $\begin{array}{l}\text { - } \quad \text { The functionalities of social } \\
\text { media are adequate. }\end{array}$ \\
\hline & $\begin{array}{l}\text { The functionalities of social media } \\
\text { make the task very easy. }\end{array}$ & $\begin{array}{ll}- & \text { The functionalities of social } \\
& \text { media make the task very easy. }\end{array}$ \\
\hline & $\begin{array}{l}\text { Social media features are compatible } \\
\text { with our CRM tasks requirements. }\end{array}$ & $\begin{array}{l}\text { Social media features are compatible } \\
\text { with our CRM tasks requirements. }\end{array}$ \\
\hline & $\begin{array}{l}\text { Our CRM task requirements closely } \\
\text { align with social media features. }\end{array}$ & $\begin{array}{l}\text { Our CRM task requirements closely } \\
\text { align with social media features. }\end{array}$ \\
\hline & $\begin{array}{l}\text { Current CRM can be easily adapted to } \\
\text { use social media. }\end{array}$ & $\begin{array}{l}\text { Current CRM can be easily adapted to } \\
\text { use social media. }\end{array}$ \\
\hline \multirow{6}{*}{ 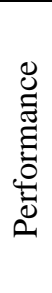 } & Using sCRM: & By Using sCRM: \\
\hline & - $\quad$ sales transactions are increased. & sales transactions are increased. \\
\hline & - $\quad$ sales volume is increased. & sales volume is increased. \\
\hline & - $\quad$ sales enquiries are increased. & - $\quad$ sales enquiries are increased. \\
\hline & - number of customers is increased. & $\begin{array}{l}\text { - number of customers is } \\
\text { increased. }\end{array}$ \\
\hline & - $\quad$ brand visibility is improved. & - $\quad$ brand visibility is improved. \\
\hline
\end{tabular}

In addition, this study developsan instrument to measure the model constructs. By operationalizing the constructs, the items for each construct were derived and revised from related theories and literatures to fit with the context of the study. Adapting the original items to the context of the study may affect the validity of the measurement. Therefore, content validity was conducted to ensure that the items sufficiently represent the content domain. Content validity provides initial evidence 
on construct validity. It also provides representativeness and clarity indicators of the items and helps to improve the instrument by considering the experts' recommendations (Yusoff, 2019). In the current study, three experts were involved in the process of content validity. The experts judged the relevance and the clarity of the items. The results showed that two items were not significantly clear (in terms of wordings), thus they were rated as not relevant to the corresponding construct. These items were revised based on the evaluators' comments. Another item was rated clear but not significantly relevant (Item no 1 in Network externalities), thus it was removed. Comments on all items and constructs were considered in the revised version of the instrument. Mainly, two items were added for the constructs; Internal Financial Resources and Government Support, so that each construct has at least three items (as recommended by the experts). These items were derived from the related literature by considering the context of SMEs' environment.

\section{Conclusion}

This study proposed an integrated model identifying the factors to be considered when studying the impact of SCRM on the SMEs' performance, more specific in developing nations. The model was constructed by integrating two theories (Network externalities and RBV) into Fit Viability Model. Based on the proposed model, the firm's performance is affected by the fitness of social media characteristics to the CRM tasks and the readiness of the firm to implement sCRM. The proposed model could help SMEs in developing nations to make decisions on adopting social media tools to efficiently manage their relationships with customers based on their requirements and capabilities. In addition, an instrument was developed to measure the variables constructing the model. Three experts were involved to assess the instrument's content validity to ensure that measurements cover all the aspects of each variable. The measurements' wordings were also checked and assessed by the experts to ensure that the items can be understandable by the respondents. The instrument can be used to collect the data to empirically examine the proposed model.

\section{Acknowledgment}

This research was funded by a matching grant research collaboration project ( $\mathrm{S} / \mathrm{O}$ number 14640) between Universiti Utara Malaysia, Sintok, Kedah, Malaysia, and UNIVERSITAS KUNINGAN, Indonesia. 


\section{Appendix}

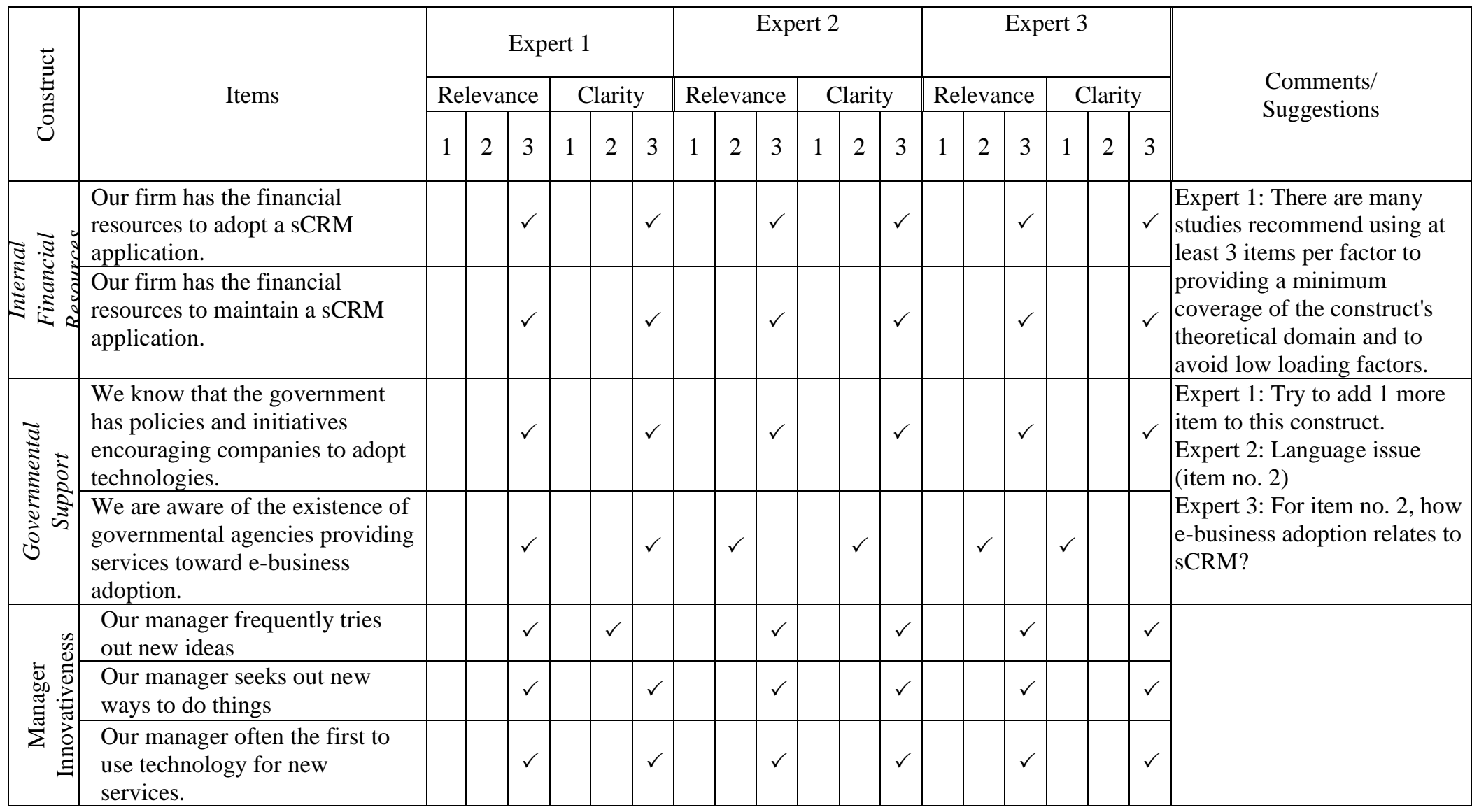




\begin{tabular}{|c|c|c|c|c|c|c|c|c|c|c|c|c|c|c|}
\hline \multirow{3}{*}{ 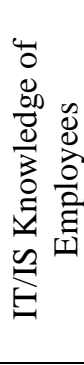 } & $\begin{array}{l}\text { Our employees are all } \\
\text { technology-literate. }\end{array}$ & $\checkmark$ & $\checkmark$ & & $\checkmark$ & & $\checkmark$ & & $\checkmark$ & & & $\checkmark$ & & \multirow{3}{*}{$\begin{array}{l}\text { Expert 2: Technology is a } \\
\text { broad concept. It is better to } \\
\text { use Information } \\
\text { Technology or Information } \\
\text { systems instead. } \\
\text { Expert 3: These items } \\
\text { represent IT knowledge in } \\
\text { general, not about using } \\
\text { social media for CRM. }\end{array}$} \\
\hline & $\begin{array}{l}\text { There is at least one employee } \\
\text { who was a technology expert. }\end{array}$ & $\checkmark$ & $\checkmark$ & & $\checkmark$ & & $\checkmark$ & & $\checkmark$ & & & $\checkmark$ & & \\
\hline & $\begin{array}{l}\text { We would rate our employees' } \\
\text { understanding of technology as } \\
\text { very good compared with other } \\
\text { small companies in the same } \\
\text { industry. }\end{array}$ & $\checkmark$ & $\checkmark$ & & $\checkmark$ & & $\checkmark$ & & $\checkmark$ & & & $\checkmark$ & & \\
\hline \multirow{5}{*}{ 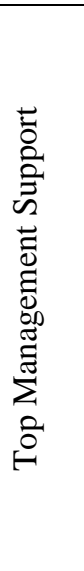 } & $\begin{array}{l}\text { Top manager is strongly } \\
\text { committed to the introduction } \\
\text { of social media tools to manage } \\
\text { the relationship with customer. }\end{array}$ & $\checkmark$ & $\checkmark$ & & & $\checkmark$ & & $\checkmark$ & & $\checkmark$ & & & $\checkmark$ & \multirow{5}{*}{$\begin{array}{l}\text { Expert 2: Language issue. } \\
\text { Is enthusiasm related to } \\
\text { support ?? (item no. 2) } \\
\text { Expert 3: wording issue in } \\
\text { item no. } 2\end{array}$} \\
\hline & $\begin{array}{l}\text { Top manager's enthusiasms in } \\
\text { adopting sCRM. }\end{array}$ & $\checkmark$ & $\checkmark$ & $\checkmark$ & & & $\checkmark$ & & & $\checkmark$ & $\checkmark$ & & & \\
\hline & $\begin{array}{l}\text { Top manager understands the } \\
\text { benefits of sCRM. }\end{array}$ & $\checkmark$ & $\checkmark$ & & & $\checkmark$ & & $\checkmark$ & & $\checkmark$ & & & $\checkmark$ & \\
\hline & $\begin{array}{l}\text { Top manager is supportive of } \\
\text { the use of social media in CRM } \\
\text { operations. }\end{array}$ & $\checkmark$ & $\checkmark$ & & & $\checkmark$ & & $\checkmark$ & & $\checkmark$ & & & $\checkmark$ & \\
\hline & $\begin{array}{l}\text { Top manager regards the } \\
\text { application of sCRM as one of } \\
\text { the firm's top priorities. }\end{array}$ & $\checkmark$ & $\checkmark$ & & & $\checkmark$ & & $\checkmark$ & & $\checkmark$ & & & $\checkmark$ & \\
\hline \multirow{3}{*}{ 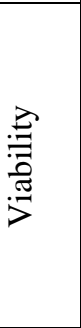 } & $\begin{array}{l}\text { The organization's capabilities } \\
\text { and current resources support } \\
\text { sCRM. }\end{array}$ & $\checkmark$ & $\checkmark$ & & & $\checkmark$ & $\checkmark$ & & $\checkmark$ & & $\checkmark$ & & & \multirow{3}{*}{$\begin{array}{l}\text { Expert 2: organization or } \\
\text { firm ? } \\
\text { Expert 3: Item no } 1 \text { is } \\
\text { Double barreled question }\end{array}$} \\
\hline & $\begin{array}{l}\text { The organization can efficiently } \\
\text { develop sCRM applications. }\end{array}$ & $\checkmark$ & $\checkmark$ & & & $\checkmark$ & & $\checkmark$ & & $\checkmark$ & & & $\checkmark$ & \\
\hline & $\begin{array}{l}\text { Social media is viable to } \\
\text { implement CRM operations in } \\
\text { our firm. }\end{array}$ & $\checkmark$ & $\checkmark$ & & $\checkmark$ & & & $\checkmark$ & & $\checkmark$ & & & $\checkmark$ & \\
\hline
\end{tabular}




\begin{tabular}{|c|c|c|c|c|c|c|c|c|c|c|c|c|c|c|}
\hline \multirow{5}{*}{ 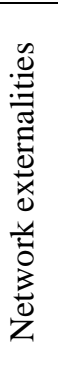 } & \multicolumn{14}{|c|}{ If more and more customers follow us on social media, then: } \\
\hline & $\begin{array}{l}\text { the quality of sCRM services is } \\
\text { increased; }\end{array}$ & $\checkmark$ & & & $\checkmark$ & $\checkmark$ & & & & & $\checkmark$ & $\checkmark$ & $\checkmark$ & \multirow{4}{*}{$\begin{array}{l}\text { Expert 2: } 19 \text {.Quality is } \\
\text { linked with the number of } \\
\text { followers }\end{array}$} \\
\hline & $\begin{array}{l}\text { variety of CRM services can be } \\
\text { provided; }\end{array}$ & & $\checkmark$ & & $\checkmark$ & & & $\checkmark$ & & & $\checkmark$ & $\checkmark$ & $\checkmark$ & \\
\hline & $\begin{array}{l}\text { the response speed of CRM } \\
\text { service is increased; }\end{array}$ & & $\checkmark$ & & $\checkmark$ & & $\checkmark$ & & & $\checkmark$ & & $\checkmark$ & $\checkmark$ & \\
\hline & $\begin{array}{l}\text { the value of information is } \\
\text { increased. }\end{array}$ & & $\checkmark$ & & $\checkmark$ & & & $\checkmark$ & & & $\checkmark$ & $\checkmark$ & $\checkmark$ & \\
\hline \multirow{7}{*}{ 居 } & \multicolumn{14}{|c|}{ In helping us to manage all company's relationships and interactions with customers and potential customers: } \\
\hline & $\begin{array}{l}\text { The functionalities of social } \\
\text { media are helpful. }\end{array}$ & & $\checkmark$ & & $\checkmark$ & & & $\checkmark$ & & & $\checkmark$ & $\checkmark$ & $\checkmark$ & \\
\hline & $\begin{array}{l}\text { The functionalities of social } \\
\text { media are adequate. }\end{array}$ & & $\checkmark$ & & $\checkmark$ & & & $\checkmark$ & & & $\checkmark$ & $\checkmark$ & $\checkmark$ & \\
\hline & $\begin{array}{l}\text { The functionalities of social } \\
\text { media make the task very easy. }\end{array}$ & & $\checkmark$ & & $\checkmark$ & & & $\checkmark$ & & & $\checkmark$ & $\checkmark$ & $\checkmark$ & \\
\hline & $\begin{array}{l}\text { Social media features are } \\
\text { compatible with our CRM tasks } \\
\text { requirements. }\end{array}$ & & $\checkmark$ & & $\checkmark$ & & & $\checkmark$ & & & $\checkmark$ & $\checkmark$ & $\checkmark$ & \\
\hline & $\begin{array}{l}\text { Our CRM task requirements } \\
\text { closely align with social media } \\
\text { features. }\end{array}$ & & $\checkmark$ & & $\checkmark$ & & & $\checkmark$ & & & $\checkmark$ & $\checkmark$ & $\checkmark$ & \\
\hline & $\begin{array}{l}\text { Current CRM can be easily } \\
\text { adapted to use social media. }\end{array}$ & & $\checkmark$ & & $\checkmark$ & $\checkmark$ & & & $\checkmark$ & & & $\checkmark$ & $\checkmark$ & \\
\hline \multirow{5}{*}{ 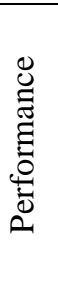 } & Using sCRM: & & & & & & & & & & & & & \multirow{5}{*}{$\begin{array}{l}\text { Expert 1: try to measure it } \\
\text { objectively using } 5 \text { Likert } \\
\text { scales. Objective } \\
\text { measurement needs } \\
\text { knowledgeable respondents } \\
\text { and have the authority to } \\
\text { answer your survey. }\end{array}$} \\
\hline & sales transactions are increased. & $\checkmark$ & & $\checkmark$ & & & & $\checkmark$ & & & $\checkmark$ & $\checkmark$ & $\checkmark$ & \\
\hline & sales volume is increased. & $\checkmark$ & & $\checkmark$ & & & & $\checkmark$ & & & $\checkmark$ & $\checkmark$ & $\checkmark$ & \\
\hline & sales enquiries are increased. & $\checkmark$ & & $\checkmark$ & & & & $\checkmark$ & & & $\checkmark$ & $\checkmark$ & $\checkmark$ & \\
\hline & $\begin{array}{l}\text { number of customers is } \\
\text { increased. }\end{array}$ & $\checkmark$ & & $\checkmark$ & & & & $\checkmark$ & & & $\checkmark$ & $\checkmark$ & $\checkmark$ & \\
\hline
\end{tabular}




\section{References}

Acker, O., Gröne, F., Akkad, F., Pötscher, F., \& Yazbek, R. (2011). Social CRM: How companies can link into the social web of consumers. Journal of Direct, Data and Digital Marketing Practice, 13(1), 3-10.

Agarwal, N. K. (2011). Verifying survey items for construct validity: A two-stage sorting procedure for questionnaire design in information behavior research. proceedings of the American Society for Information Science Technology, 48(1), 18.

Ahani, A., Rahim, N. Z. A., \& Nilashi, M. (2017). Forecasting social CRM adoption in SMEs: A combined SEM-neural network method. Computers in Human Behavior, 75, 560-578.

Aldoseri, S., Al Mubarak, M., \& El Hajjar, S. (2019). Evaluating the Impact of Social CRM on SMEs' Performance. Paper presented at the International Conference on Innovation and Entrepreneurship.

Baas, P., \& van Rekom, C.-r. D. J. (2010). Task-Technology Fit in the Workplace. Master Thesis, Rotterdam School of Management, Erasmus University.

Baird, C. H., \& Parasnis, G. (2011). From social media to social CRM-what customers want. IBM Global Services, Somers.

Banwo, A. O., Du, J., \& Onokala, U. (2017). The determinants of location specific choice: small and medium-sized enterprises in developing countries. Journal of Global Entrepreneurship Research, 7(1), 16.

Bardicchia, M. (2020). Digital CRM: Strategies and Emerging Trends: Building Customer Relationship in the Digital Era: Kindle.

Barney, J. (1991). Firm resources and sustained competitive advantage. Journal of management, 17(1), 99-120.

Bhattacherjee, A. (2012). Social science research: Principles, methods, and practices.

Bridge, L. (2017). Social CRM Applications and impact in small businesses. (PhD), Liberty University, 
Charoensukmongkol, P., \& Sasatanun, P. (2017). Social media use for CRM and business performance satisfaction: The moderating roles of social skills and social media sales intensity. Asia Pacific Management Review, 22(1), 25-34.

Cheng, C. C., \& Shiu, E. C. (2019). How to enhance SMEs customer involvement using social media: The role of Social CRM. J International Small Business Journal, 37(1), 22-42.

Choudhury, M. M., \& Harrigan, P. (2014). CRM to social CRM: the integration of new technologies into customer relationship management. Journal of Strategic Marketing, 22(2), 149-176.

Davis, L. L. (1992). Instrument review: Getting the most from a panel of experts. Applied nursing research, 5(4), 194-197.

Diffley, S., McCole, P., \& Carvajal-Trujillo, E. (2018). Examining social customer relationship management among Irish hotels. International Journal of Contemporary Hospitality Management, 30(2), 1072-1091.

Dyche, J. (2002). The CRM handbook: A business guide to customer relationship management: Addison-Wesley Professional.

Faase, R., Helms, R., \& Spruit, M. (2011). Web 2.0 in the CRM domain: defining social CRM. International Journal of Electronic Customer Relationship Management, 5(1), 1-22.

Goodhue, D. L., \& Thompson, R. L. (1995). Task-technology fit and individual performance. MIS quarterly, 213-236.

Gu, V., Davis, J., Cao, R., \& Vogt, J. (2017). The effect of externalities on adoption of social customer relationship management (SCRM). International Journal of Quality Innovation, 3(1), 11.

Guha, S., Harrigan, P., \& Soutar, G. (2018). Linking social media to customer relationship management (CRM): A qualitative study on SMEs. Journal of Small Business Entrepreneurship, 30(3), 193-214.

Harrigan, P., \& Miles, M. (2014). From e-CRM to s-CRM. Critical factors underpinning the social CRM activities of SMEs. Small Enterprise Research, 21(1), 99-116. 
Harrigan, P., Soutar, G., Choudhury, M. M., \& Lowe, M. (2015). Modelling CRM in a social media age. Australasian Marketing Journal (AMJ), 23(1), 27-37.

Hasani, T., Bojei, J., \& Dehghantanha, A. (2017). Investigating the antecedents to the adoption of SCRM technologies by start-up companies. Telematics and Informatics, 34(5), 655-675.

Hassan, S. H., Mohamed Haniba, N. M., \& Ahmad, N. H. (2019). Social customer relationship management (s-CRM) among small-and medium-sized enterprises (SMEs) in Malaysia. International Journal of Ethics and Systems, 35(2), 284-302.

Ikechukwu, A. J. (2019). Assessment of organizational performance of private manufacturing companies: the impact of supply chain management responsiveness. Journal of System Management Sciences, 9(3), 26-44.

Jinyoung Shin, J. O., Dae-Yul Jeong. (2020). An Empirical Study on the Social Marketing of Companies in India. Journal of System and Management Sciences, 10(4), 86-101.

Kling, R. (1980). Social analyses of computing: Theoretical perspectives in recent empirical research. ACM Computing Surveys (CSUR), 12(1), 61-110.

Küpper, T. (2016). Impact of Social CRM Technology Use on Social CRM Performance: An Organizational Perspective. Universität St. Gallen,

Küpper, T., Lehmkuhl, T., Wittkuhn, N., Wieneke, A., \& Jung, R. (2015). Social CRM Performance Model: An Empirical Evaluation. Paper presented at the Bled eConference.

Lehmkuhl, T. (2014). Towards Social CRM: A Model for Deploying Web 2.0 in Customer Relationship Management. Difo-Druck,

Lehmkuhl, T., \& Jung, R. (2013). Towards social CRM-scoping the concept and guiding research.

Li, J. C. (2020). Roles of Individual Perception in Technology Adoption at Organization Level: Behavioral Model versus TOE Framework. Journal of System Management Sciences, 10(3), 97-118.

Liang, T.-P., Huang, C.-W., Yeh, Y.-H., \& Lin, B. (2007). Adoption of mobile technology in business: a fit-viability model. Industrial management \& data systems, 107(8), 1154-1169. 
Lynn, M. R. (1986). Determination and quantification of content validity. Nursing research, 35(6), 382-386.

Markus, M. L., \& Robey, D. (1988). Information technology and organizational change: causal structure in theory and research. Management science, 34(5), 583598.

Marolt, M. (2018). Social CRM adoption and its influence on customer relationship performance-SMEs perspective. Univerza v Mariboru (Slovenia),

Marolt, M., Pucihar, A., \& Zimmermann, H.-D. (2015). Social CRM adoption and its impact on performance outcomes: A literature review. Organizacija, 48(4), 260271.

Marolt, M., Zimmermann, H.-D., \& Pucihar, A. J. E. E. (2018). Exploratory study of social CRM use in SMEs. 29(4), 468-477.

Melville, N., Kraemer, K., \& Gurbaxani, V. (2004). Information technology and organizational performance: An integrative model of IT business value. MIS quarterly, 28(2), 283-322.

Mohammed, F., Ibrahim, O., Nilashi, M., \& Alzurqa, E. (2017). Cloud computing adoption model for e-government implementation. Information Development, 33(3), 303-323.

Parveen, F., Jaafar, N. I., \& Ainin, S. (2016). Social media's impact on organizational performance and entrepreneurial orientation in organizations. Management Decision.

Polit, D. F., \& Beck, C. T. (2006). The content validity index: are you sure you know what's being reported? Critique and recommendations. Research in nursing \& health, 29(5), 489-497.

Polit, D. F., Beck, C. T., \& Owen, S. V. (2007). Is the CVI an acceptable indicator of content validity? Appraisal and recommendations. Research in nursing \& health, 30(4), 459-467.

Rapp, A., Trainor, K. J., \& Agnihotri, R. (2010). Performance implications of customer-linking capabilities: Examining the complementary role of customer orientation and CRM technology. Journal of Business Research, 63(11), 1229-1236. 
Reinhold, O., \& Alt, R. (2012). Social Customer Relationship Management: State of the Art and Learnings from Current Projects. Paper presented at the Bled eConference.

Rodriguez, M., Peterson, R. M., \& Ajjan, H. (2015). CRM/social media technology: impact on customer orientation process and organizational sales performance. In Ideas in Marketing: Finding the New and Polishing the Old (pp. 636-638): Springer.

Sigala, M. (2011). eCRM 2.0 applications and trends: The use and perceptions of Greek tourism firms of social networks and intelligence. Computers in Human Behavior, 27(2), 655-661.

Sophonthummapharn, K. (2009). The adoption of techno-relationship innovations: A framework for electronic customer relationship management. Marketing Intelligence Planning, 27(3), 380-412.

Sorasalmi, T., \& Tuovinen, J. (2016). Entering emerging markets: A dynamic framework. In Dynamics in logistics (pp. 675-683): Springer.

Tjan, A. K. (2001). Finally, a way to put your Internet portfolio in order. Harvard Business Review, 79(2), 76.

Trainor, K. J., Andzulis, J. M., Rapp, A., \& Agnihotri, R. (2014). Social media technology usage and customer relationship performance: A capabilities-based examination of social CRM. Journal of Business Research, 67(6), 1201-1208.

Wang, Z., \& Kim, H. G. (2017). Can social media marketing improve customer relationship capabilities and firm performance? Dynamic capability perspective. Journal of Interactive Marketing, 39, 15-26.

Wittkuhn, N., Lehmkuhl, T., Küpper, T., \& Jung, R. (2015). Social CRM Performance Dimensions: A Resource-based View and Dynamic Capabilities Perspective. Paper presented at the Bled eConference.

Yawised, K., Torugsa, N., \& O'Donohue, W. (2017). Exploring social customer relationship management in Australian small and medium enterprises. International Journal of Globalisation and Small Business, 9(4), 222-251.

Yu, J., \& Lee, Y.-C. J. 인. (2018). Examining the effect of social CRM competence and capability on CRM performance: empirical evidence from enterprises in China. 18(6), 85-103. 
Yusoff, M. S. B. (2019). ABC of content validation and content validity index calculation. J Resource, 11(2), 49-54.

Zhou, Z., Xiao, Z., Liu, Q., \& Ai, Q. (2013). An analytical approach to customer requirement information processing. Enterprise Information Systems, 7(4), 543-557. 